\title{
3D Printing as an Alternative to Casting, Forging and Machining Technologies?
}

Michaela Fousová, Dalibor Vojtěch, Jiří Kubásek, Drahomír Dvorský, Markéta Machová

Faculty of Chemical Technology, Department of Metals and Corrosion Engineering, University of Chemistry and Technology Prague, 16628 Prague 6. Czech Republic. E-mail: fousovam@vscht.cz, dalibor.vojtech@vscht.cz, jiri.kubasek@vscht.cz,dvorskyd@vscht.cz, machovam@vscht.cz

3D printing technology has recently extended to metallic materials and allows now to produce 3D models directly from metallic powders. There are several methods of 3D metal printing, such as Selective Laser Sintering (SLS), Direct Metal Laser Sintering (DMLS), Electron beam melting (EBM) or Selective laser melting (SLM). Compared to conventional technologies of casting, forging and machining, these methods offer many advantages. The most important is shape variety allowing preparation of very complicated shapes and designs, which would be impossible to reach by classical techniques. Moreover, there is practically no material loss, since the remaining powder can be recycled and reused in other manufacturing processes. That is one of important cost savings. However, for now, the metal 3D printing is unable to compete the price of large-lot production. In present paper, it is demonstrated that by the SLM technology it is possible to achieve comparable material properties of stainless steel AISI 316L as by conventional technologies and therefore, this method offers a suitable alternative.

Keywords: 3D printing, SLM, AISI 316L, mechanical properties

\section{Acknowledgement}

Authors wish to thank the Czech Science Foundation (project no. P108/12/G043) and specific university research (MSMT no. 20/2015) for the financial support of this research.

\section{References}

[1] OSAKADA, K., SHIOMI M. (2006). Flexible manufacturing of metallic products by selective laser melting of powder. In: International Journal of Machine Tools and Manufacture, Vol. 46, No. 11, pp. 1188-1193. Elsevier Ltd.

[2] PETZOLD, R., ZEILHOFER, H. F., KALENDER, W. A. (1999). Rapid prototyping technology in medicine basics and applications. In: Computerized Medical Imaging and Graphics, Vol. 23, No. 5, pp. 277-284. Elsevier Ltd.

[3] SEDLAK, J., SLANY, M., FIALA, Z., JAROS, A. (2015). Production Method of Implant Prototype of Knee-Joint Femoral Component. In: Manufacturing Technology, Vol. 15, No. 2, pp. 195-204.

[4] LINDA, M., MÜlleR, M., CHOTĚBORSKÝ, R. (2014). Evaluation of Mechanical Properties of Samples Printed by FDM Method. In: Manufacturing Technology, Vol. 14, No. 1, pp. 56-60.

[5] WANG, X. C., ET AL. (2002). Direct Selective Laser Sintering of Hard Metal Powders: Experimental Study and Simulation. In: The International Journal of Advanced Manufacturing Technology, Vol. 19, No. 5, pp. 351-357. Springer-Verlag London Ltd.

[6] KUMAR, S. (2003). Selective laser sintering: A qualitative and objective approach. In: JOM, Vol. 55, No. 10, pp. 43-47. Springer-Verlag.

[7] VERMA, A., TYAGI, S., YANG, K. (2015). Modeling and optimization of direct metal laser sintering process. In: The International Journal of Advanced Manufacturing Technology, Vol. 77, No. 5-8, pp. 847-860. Springer, London.

[8] VENKATESH, K.V., NANDINI, V.V. (2013). Direct Metal Laser Sintering: A Digitised Metal Casting Technology. In: The Journal of Indian Prosthodontic Society, Vol. 13, No.4, pp. 389-392. Springer. India.

[9] MAZZOLI, A. (2013). Selective laser sintering in biomedical engineering. In: Medical \& Biological Engineering \& Computing, Vol. 51, No. 3, pp. 245-256. Springer-Verlag.

[10]HEINL, P., ET AL. (2007). Cellular Titanium by Selective Electron Beam Melting. In: Advanced Engineering Materials, Vol. 9, No. 5, pp. 360-364. WILEY-VCH Verlag GmbH \& Co.

[11]PARTHASARATHY, J., ET AL. (2010). Mechanical evaluation of porous titanium (Ti6Al4V) structures with electron beam melting (EBM). In: Journal of the Mechanical Behavior of Biomedical Materials, Vol. 3, No. 3, pp. 249-259. Elsevier Ltd. 
[12] SATEESH, N. H., ET AL. (2014). Microstructure and Mechanical Characterization of Laser Sintered Inconel-625 Superalloy. In: Procedia Materials Science, Vol. 5, pp. 772-779. Elsevier Ltd. India.

[13]BAČA, A., KONEČNÁ, R., NICOLETTO, G., KUNZ, L. (2015) Effect of Surface Roughness on the Fatigue Life of Laser Additive Manufactured Ti6Al4V Alloy. In: Manufacturing Technology, Vol. 15, No. 4, pp. 498-502.

[14]BARUCCA, G., ET AL. (2015). Structural characterization of biomedical Co-Cr-Mo components produced by direct metal laser sintering. In: Materials Science and Engineering: C, Vol. 48, pp. 263-269. Elsevier Ltd.

[15]MURR, L. E., ET AL. (2012). Fabrication of Metal and Alloy Components by Additive Manufacturing: Examples of 3D Materials Science. In: Journal of Materials Research and Technology, Vol. 1, No. 1, pp. 42-54. Elsevier Editora Ltda. Brazil.

[16]SIMCHI, A., PETZOLDT, F., POHL, H. (2003). On the development of direct metal laser sintering for rapid tooling. In: Journal of Materials Processing Technology, Vol. 141, No. 3, pp. 319-328. Elsevier B.V.

[17]JELIS, E., ET AL. (2015). Metallurgical and Mechanical Evaluation of 4340 Steel Produced by Direct Metal Laser Sintering. In: JOM, Vol. 67, No. 3, pp. 582-589. Springer US.

Paper number: M2015147

Copyright (C) 2015. Published by Manufacturing Technology. All rights reserved. 